\title{
SISTEM PREDIKSI KETEPATAN KELULUSAN MAHASISWA BERDASARKAN DATA AKADEMIK DAN NON AKADEMIK MENGGUNAKAN METODE K-MEANS (STUDI KASUS : UNIVERSITAS CATUR INSAN CENDEKIA)
}

\author{
Mochamad Rizky Alvin Fernanda ${ }^{1}$, Petrus Sokibi², Rifqi Fahrudin ${ }^{3}$ \\ Universitas Catur Insan Cendekia \\ Jl. Kesambi No. 202, Cirebon \\ e-mail: rizkyalvin5@gmail.com ${ }^{1}$, petrus.sokibi@cic.ac.id ${ }^{2}$,rifqifhrdn@gmail.com ${ }^{3}$
}

\begin{abstract}
ABSTRAK
Saat ini perkembangan teknologi informasi telah berkembang sangat pesat mengakibatkan ketersediaan dan keberagaman data pun semakin meningkat. Begitu pula yang dirasakan oleh pihak program studi Informatika, Universitas Catur Insan Cendekia. Karena banyaknya data mahasiswa saat ini belum dimanfaatkan secara maksimal dan efisien, pihak prodi masih merasa kesulitan dalam menganalisis evaluasi tingkat kelulusan mahasiswa dikarenakan data yang belum terintegrasi dalam sebuah basis data. Untuk meningkatkan dan mempertahankan kualitas kelulusan dan akreditasi program studi, diperlukan data data tersebut dapat dimanfaatkan sebagai sumber informasi strategis bagi program studi untuk melakukan klasifikasi tingkat kelulusan mahasiswa dengan menggunakan teknik data mining. K- means clustering merupakan salah satu metode data clustering non-hirarki yang mengelompokan data dalam bentuk satu atau lebih cluster/kelompok. software yang digunakan untuk mendesain web yaitu Coreldraw X7, Sublime Text 2, dan untuk desain UML kami menggunakan Enterprise Architect. Setelah menganalisis masalah dalam evaluasi tingkat kelulusan mahasiswa maka Universitas Catur Insan Cendekia dapat mengimplementasikan sistem prediksi kelulusan mahasiswa menggunakan metode K-means Clustering sebagai hasil prediksinya
\end{abstract}

Kata kunci : Data Mining, Kelulusan Mahasiswa, K-Means Clustering, Basis Data, Universitas Catur Insan Cendekia

\begin{abstract}
At present the development of information technology has developed very rapidly resulting in the availability and diversity of data has also increased The same thing is felt by the Informatics study program, Universitas Catur Insan Cendekia. Because a lot of student data currently untapped maximally and efficiently, the study program still feels difficulties in analyzing evaluations student graduation rate because the data is not integrated in a database. To improve and maintain quality graduation and accreditation of study programs, The data is needed can be utilized as a source of strategic information for study programs to do the classification student graduation rate students by using data mining techniques. $K$ - means clustering is a data method clustering non-hirarki which groups data in one or more forms cluster / group. While the sotware used to design a web that is Corelldraw X7, Sublime Text and for UML design we use Enterprise Architect. After analyzing the problems in evaluating student graduation rates, Catur Insan Cendekia University can implement a student graduation prediction system using the K-Means Clustering method as the prediction result.
\end{abstract}

Keywords : Data Mining, Student Graduation Prediction, K-Means Clustering, Database, Universitas Catur Insan Cendekia. 


\section{Pendahuluan}

Saat ini perkembangan teknologi informasi telah berkembang sangat pesat mengakibatkan ketersediaan dan keberagaman data pun semakin meningkat. Begitu pula yang dirasakan oleh pihak program studi Informatika, Universitas Catur Insan Cendekia. Seiring dengan perkembangan teknologi informasi, pihak Universitas dituntut untuk memiliki keunggulan bersaing dengan memanfaatkan semua sumber daya yang dimiliki. Pemanfaatan data yang ada tidak cukup hanya mengandalkan data operasional saja, tetapi diperlukan suatu analisis data untuk menggali informasi - informasi yang ada.

Karena banyaknya data mahasiswa saat ini belum dimanfaatkan secara maksimal dan efisien, pihak prodi masih merasa kesulitan dalam menganalisis evaluasi tingkat kelulusan mahasiswa dikarenakan data yang belum terintegrasi dalam sebuah basis data. Padahal pihak prodi perlu untuk melakukan evaluasi tingkat kelulusan untuk meningkatkan dan mempertahankan kualitas kelulusan dan akreditasi program studi, sehingga untuk memaksimalkan data informasi kelulusan diperlukan data data tersebut dapat dimanfaatkan sebagai sumber informasi strategis bagi program studi untuk melakukan klasifikasi tingkat kelulusan mahasiswa dengan menggunakan teknik data mining.

Aplikasi data mining menggunakan Algoritma Naive Bayes untuk memprediksi ketepatan waktu lulus mahasiswa. Pada penelitian aplikasi data mining ini menerapkan teknik mengklasifikasi menggunakan Algoritma Naive Bayes sebagai metode penyelesaian yang ada [1]. Analisis Implementasi sistem Online Analytical Processing dan klasifikasi ketepatan waktu lulus dan undur diri mahasiswa teknik informatika universitas telkom menggunakan random forest. Aplikasi ini dibangun menggunakan sistem Online Analytical Processing yang meliputi ektrasi data operasional ke dalam data warehouse kemudian dilanjutkan kegiatan teknik data mining untuk mengklasifikasinya [2]. Analisis Algoritma K-Nearest Neightbors dalam prediksi waktu kelulusan mahasiswa. Hasil penelitian ini akan membandingkan data real dan hasil tingkat akurasi algoritma yang akan disajikan dalam ROC Curve [3].

Berdasarkan latar belakang diatas, maka penulis tertarik untuk membangun sistem prediksi ketepatan kelulusan mahasiswa. Yang membedakan dengan penelitian selanjutnya adalah penelitian ini menggunakan metode $K$-Means untuk menghasilkan data pengelompokan mahasiswa yang lulus dan undur diri secara akurat. Kelebihan dari metode $K$-Means ini adalah menghasilkan analisis sistem dengan clustering atau pengelompokkan secara akurat. Kekurangan dari metode K-Means adalah hanya bisa menghasilkan data clustering atau kelompok. Dengan adanya sistem ini akan akan memberikan kemudahan bagi pihak prodi untuk mengetahui pola, penyebab ketepatan waktu lulus dan undur diri mahasiswa Universitas Catur Insan Cendekia. Oleh karena itu pada penelitian ini penulis membuat judul "Sistem Prediksi Ketepatan Kelulusan Mahasiswa Berdasarkan Data Akedemik Dan Non-Akademik Menggunakan Metode K-Means (Studi Kasus : Universitas Catur Insan Cendekia)”.

\subsection{Identifkasi Masalah}

Berdasarkan latar belakang masalah diatas, maka penulis menguraikan identifikasi permasalahan sebagai berikut :

1. Belum tersedianya aplikasi prediksi ketepatan kelulusan mahasiswa di Universitas Catur Insan Cendekia sehingga dibutuhkan sistem aplikasi web untuk menentukan kelulusan mahasiswa.

2. Kaprodi masih menggunakan cara manual untuk mencari data mahasiswa yang lulus tepat waktu dan tidak lulus menggunakan excel.

3. Banyaknya data mahasiswa yang belum dimanfaatkan secara maksimal dan belum digunakan untuk menentukan kelulusan mahasiswa.

\subsection{Batasan Masalah}

Penulis membatasi permasalahan dalam penulisan ini agar pembahasan tidak menyimpang dari tujuan, maka dilakukan pembatasan masalah sebagai berikut :

1. Data yang digunakan merupakan data akademik (IPK dan SKS) dan data non akademik (Administrasi Keuangan, Pengambilan Cuti, Status) mahasiswa aktif semester 6 di Universitas

Sistem Prediksi Ketepatan Kelulusan Mahasiswa Berdasarkan Data Akedemik Dan Non-Akademik Menggunakan Metode K-Means (Studi Kasus : Universitas Catur Insan Cendekia) (Mochamad Rizky Alvin Fernanda, Petrus Sokibi, Rifqi Fahrudin) 


\section{Catur Insan Cendekia.}

2. Sistem ini menggunakan metode $K$-Means untuk pengelompokkan data.

3. Login user ini hanya dibatasi Kaprodi dan BAAK.

4. Aplikasi prediksi kelulusan mahasiswa ini digunakan untuk program studi jenjang strata $1(S 1)$

\subsection{Tujuan Penelitian}

Adapun tujuan dibuatnya prototype ini adalah sebagai berikut :

1. Memberikan informasi ketepatan kelulusan mahasiswa berdasarkan hasil analisis data akademik dan non akademik.

2. Menerapkan metode $K$-Means untuk pengelompokkan data hasil analisis sistem.

3. Memudahkan kaprodi untuk melihat data mahasiswa yang lulus tepat waktu dan tidak tepat waktu.

\section{KAJIAN PUSTAKA}

\subsection{Sistem}

Suatu sistem adalah Sistem adalah sebuah tatanan yang terdiri atas sejumlah komponen fungsional (dengan tugas atau fungsi khusus) yang saling berhubungan dan secara bersama-sama bertujuan untuk memenuhi suatu proses/pekerjaan tertentu. Sebagai contoh, sistem kendaraan terdiri dari : komponen starter, komponen pengapian, komponen penggerak, komponen pengerem, komponen kelistrikanspeedometer, lampu dan lain-lain. Komponen-komponen tersebut diatas memiliki tujuan yang sama, yaitu membuat kendaraan tersebut bisa dikendarai dengan nyaman dan aman. Contoh lain yaitu sistem perguruan tinggi, yang terdiri dari dosen, mahasiswa, kurikulum, dan lain-lain. Sistem ini bertujuan untuk menghasilkan mahasiswa-mahasiswa yang memiliki kemampuan di bidang ilmunya [4].

\subsection{Prediksi}

Prediksi adalah sesuatu yang dilakukan secara sistematis untuk memperkirakan sesuatu yang mungkin terjadi di masa depan berdasarkan informasi masa lalu dan sekarang, sehingga perbedaan antara sesuatu yang terjadi dan hasil yang diharapkan dapat diminimalkan. Prediksi tidak harus memberikan jawaban yang pasti untuk acara yang akan terjadi, tetapi cobalah untuk menemukan jawabannya sedekat mungkin yang akan terjadi [5].

\subsection{Kelulusan Mahasiswa}

Mahasiswa sering disebut kelompok masyarakat yang memiliki ciri intelektualitas yang lebih luas dibandingkan dengan kelompok seusia mereka yang bukan mahasiswa ataupun kelompok usia lain yang dibawah mereka. Dengan intelektualitasnya mahasiswa akan mampu menghadapi dan mencari permasalahan secara sistematis yang nantinya diterapkan dalam kehidupan sehari- hari agar bisa bersaing dalam dunia kerja. Kelulusan mahasiwa adalah hal yang penting diperhatikan, karena persentase jumlah kelulusan mempengaruhi penilaian pemerintah serta mempengaruhi status akreditasi program studi [6] .

\subsection{Metode K-Means}

Algoritma K-means merupakan salah satu algoritma dengan partitional, karena K-Means didasarkan pada penentuan jumlah awal kelompok dengan mendefinisikan nilai centroid awalnya. $K$ means clustering merupakan salah satu metode data clustering non-hirarki yang mengelompokan data dalam bentuk satu atau lebih cluster/kelompok. Data-data yang memiliki karakteristik yang sama dikelompokan dalam satu clusterl kelompok dan data yang memiliki karakteristik yang berbeda dikelompokan dengan cluster/kelompok yang lain sehingga data yang berada dalam satu cluster/kelompok memiliki tingkat variasi yang kecil [7]. K-Means Clustering merupakan algoritma clustering yang berulang-ulang. Algoritma K-Means dimulai dengan pemilihan secara acak K, K disini merupakan banyaknya cluster yang ingin dibentuk. Kemudian tetapkan nilai-nilai K secara random, untuk sementara nilai tersebut menjadi pusat dari cluster atau biasa disebut dengan centroid, mean atau "means". Hitung jarak setiap data yang ada terhadap masing-masing centroid menggunakan rumus Euclidian hingga ditemukan jarak yang paling dekat / minimum dari setiap data dengan centroid. Klasifikasikan setiap data berdasarkan kedekatannya dengan centroid. Lakukan langkah tersebut hingga nilai centroid tidak berubah [8].Adapun perhitungan manual dan cara kerja dari metode $K$-Means adalah dijelaskan sebagai berikut :

1. Menentukan k sebagai jumlah cluster yang ingin di bentuk.

2. Membangkitkan nilai random untuk pusat cluster awal (centroid) 
3. Menghitung jarak setiap data input terhadap masing - masing centroid menggunakan rumus jarak Eucliden (Eucliden Distance) hingga ditemukan jarak yang paling dekat dari setiap data dengan centroid. Dimana : xi adalah data kriteria $\mu \mathrm{j}$ adalah centroid pada kluster ke-j.

$$
\mathrm{d}(\mathrm{xi}, \mu \mathrm{j})=\sqrt{(\mathrm{xi}-\mu \mathrm{j})^{2}}(3)
$$

4. Mengklasifikasikan setiap data berdasarkan kedekatannya dengan centroid (jarak terkecil).

5. Memperbaharui nilai centroid. Nilai centroid baru diperoleh dari rata- $\quad$ rata cluster yang bersangkutan dengan menggunakan rumus :

$$
\mu \mathrm{i}(t+1)=\frac{1}{N s j} \sum j C S j X_{j}(5)
$$

Dimana : $\mu \mathrm{j}(\mathrm{t}+1)$ adalah centroid baru pada iterasi ke $(\mathrm{t}+1) \mathrm{Nsj}$ adalah banyak data pada cluster $\mathrm{sj}$

6. Melakukan perulangan dari langkah 2 hingga 5 , sampai anggota tiap cluster tidak ada yang berubah Jika langkah f telah terpenuhi maka nilai pusat cluster pada iterasi terakhir akan digunakan sebagai parameter untuk menentukan klasifikasi data.

\section{METODE PENELITIAN}

\subsection{Metode}

Tahapan proses metodologi penelitian yang dilakukan dalam penelitian ini menggunakan metode Rapid Application Development (RAD) seperti gambar berikut :

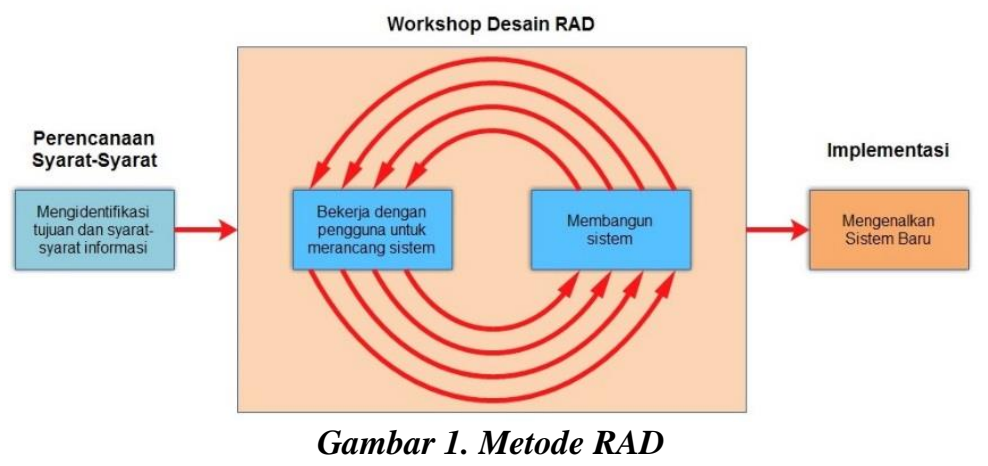

Metode RAD memiliki fase-fase melakukan perencanaan syarat-syarat kebutuhan sistem, melibatkan pengguna untuk merancang sistem dan membangun sistem (kegiatan ini dilakukan secara berulang-ulang hingga mencapai kesepakatan bersama) dan terakhir tahap implementasi [9].

Adapun tahapan langkah-langkah yang dilakukan peneliti berdasarkan model Rapid Application Development adalah sebagai berikut.

1. Analisa Persyaratan

Tahapan analisa persyaratan bertujuan untuk mengidentifikasi tujuan, kebutuhan, batasan dan objektifitas dari sistem yang akan dibangun dengan melakukan pengumpulan data melalui pengguna.

2. Desain Workshop (Planning)

Pada tahap desain workshop bertujuan untuk merancang seluruh kegiatan yang berjalan diorganisasi secara keseluruhan dan meningkatkan pemahaman atas permasalahan yang terjadi berdasarkan analisa yang telah dilakukan. Pada tahap ini peneliti mendesain seluruh aktifitas yang dilakukan di dalam organisasi dengan deskripsi proses bisnis, model struktural dan model perilaku, serta desain lapisan interaksi komputer manusia. Hasil yang didapatkan berupa pemodelan, rancangan database dan desain antar muka, dari tahapan ini.

Sistem Prediksi Ketepatan Kelulusan Mahasiswa Berdasarkan Data Akedemik Dan Non-Akademik Menggunakan Metode K-Means (Studi Kasus : Universitas Catur Insan Cendekia) (Mochamad Rizky Alvin Fernanda, Petrus Sokibi, Rifqi Fahrudin) 


\section{Implementasi}

Pada tahapan implementasi bertujuan untuk mengimplementasikan metode, program sesuai dengan kebutuhan sistem. Tahapan yang dilakukan untuk membangun sistem sesuai dengan pemodelan yang dibangun.

\subsection{Analisis}

Analisis merupakan proses penguraian konsep ke dalam bagian-bagian yang lebih sederhana, sehingga struktur logisnya menjadi jelas. Analisis merupakan metode untuk menguji, menilai, dan memahami sistem pemikiran yang kompleks dengan memecahnya ke dalam unsur-unsur yang lebih sederhana sehingga hubungan antar unsur-unsur itu menjadi jelas.

\subsubsection{Perancangan Sistem}

Dalam pembuatan aplikasi ini menggunakan perancangan sistem, diantaranya adalah :

\section{1). Flowchart Diagram}

Dalam Flowchart diagram ini menjelaskan alur jalannya suatu kegiatan pada sistem aplikasi. prediksi kelulusan mahasiswa terdapat dua aktor yaitu admin dan kaprodi.

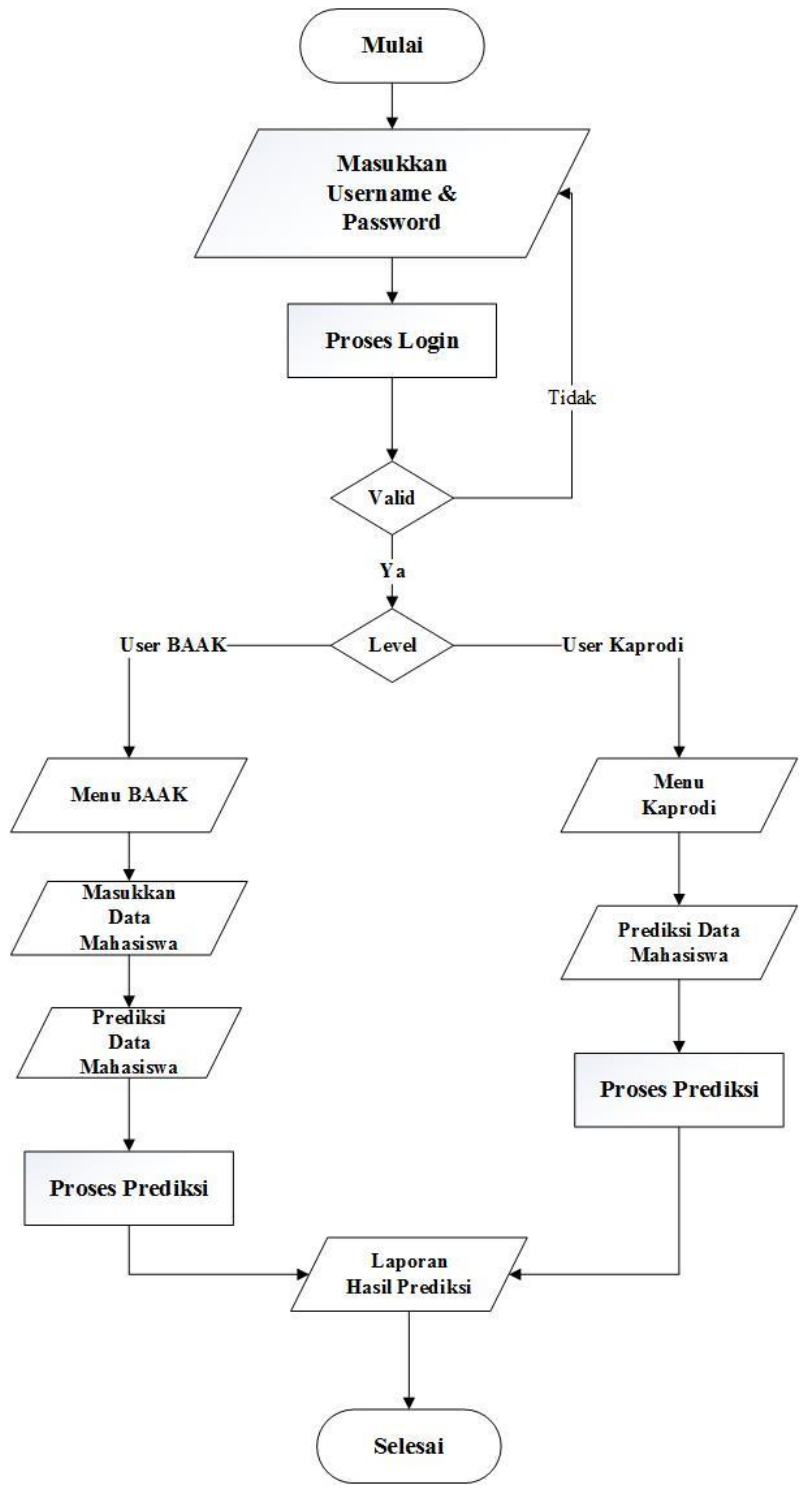

Gambar 2. Flowchart Diagram 


\section{2). Usecase Diagram}

Usecase Diagram menjelaskan alur kegiatan mulai login sampai mengelola menu pada web per aktor.

a. Usecase Diagram BAAK

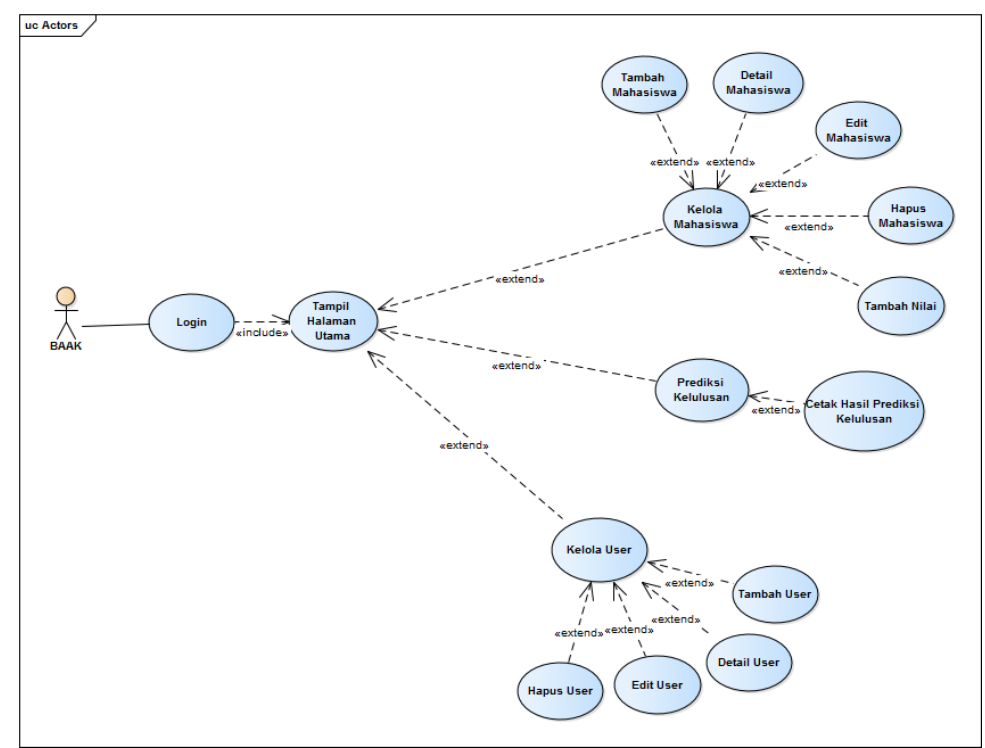

Gambar 3. Usecase Diagram BAAK

b. Usecase Diagram Kaprodi

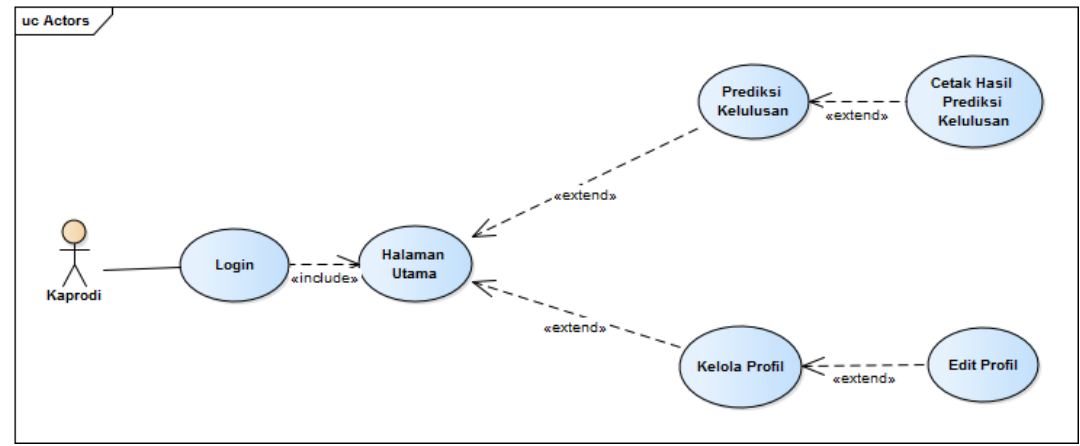

Gambar 4. Usecase Diagram Kaprodi

\section{3). Activity Diagram}

Activity Diagram menggambarkan berbagai alur aktivitas dalam sistem yang dirancang, bagaimana masing-masing alir berawal, decision yang mungkin terjadi, dan bagaimana mereka berakhir. a. Activity Diagram BAAK

Sistem Prediksi Ketepatan Kelulusan Mahasiswa Berdasarkan Data Akedemik Dan Non-Akademik Menggunakan Metode K-Means (Studi Kasus : Universitas Catur Insan Cendekia) (Mochamad Rizky Alvin Fernanda, Petrus Sokibi, Rifqi Fahrudin) 


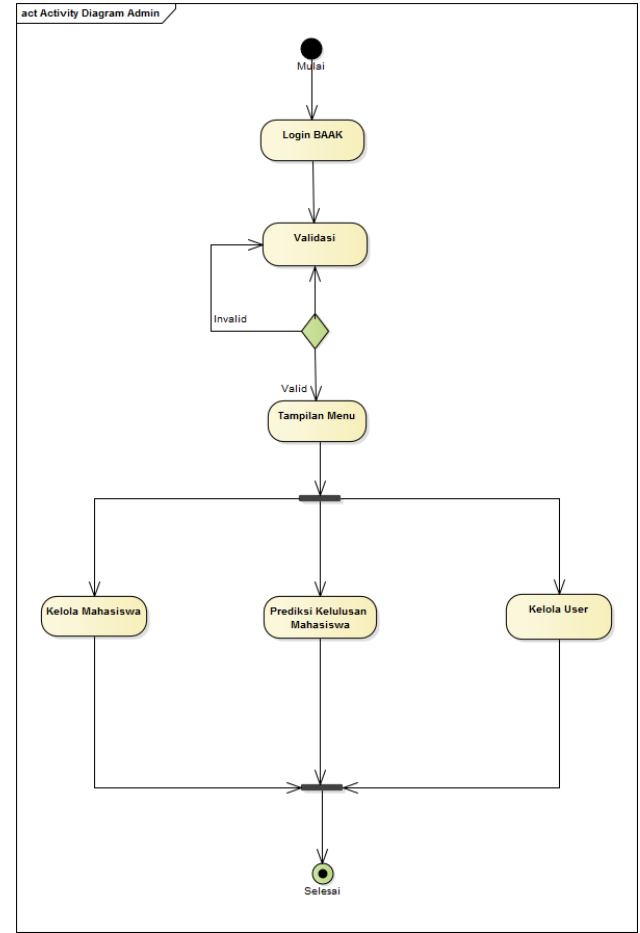

Gambar 5. Activity Diagram BAAK

b. Activity Diagram BAAK

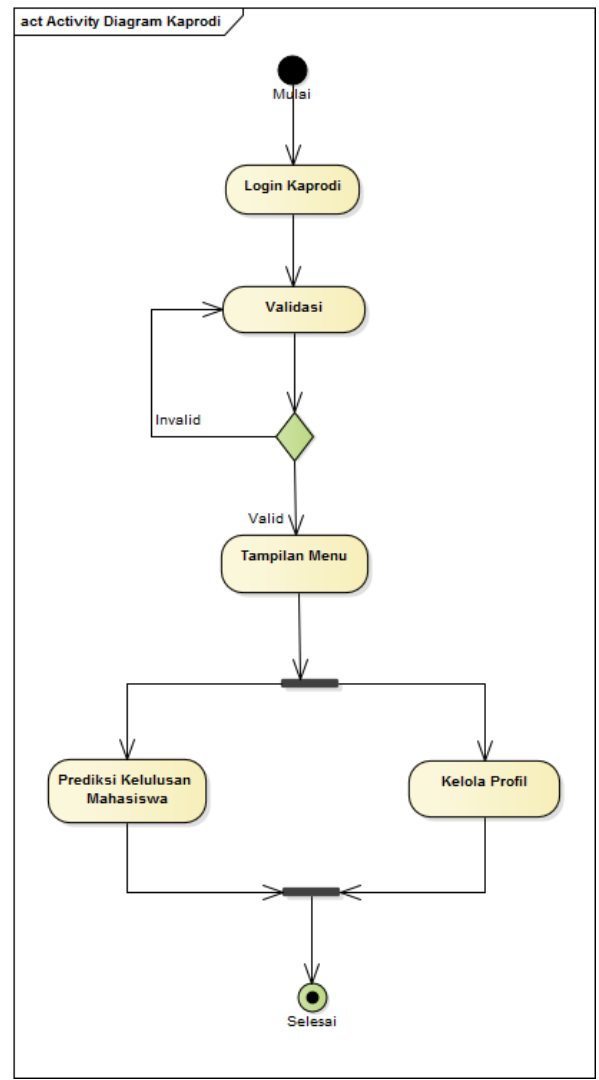

Gambar 6. Activity Diagram Kaprodi 
4). Sequence Diagram

Sequence Diagram adalah diagram yang menggambarkan interaksi antar objek. Sequence Diagram secara khusus menjabarkan behavior sebuah skenario tunggal. Diagram tersebut menunjukan sejumlah objek contoh dan pesan-pesan yang melewati objek ini dalam sebuah usecase.

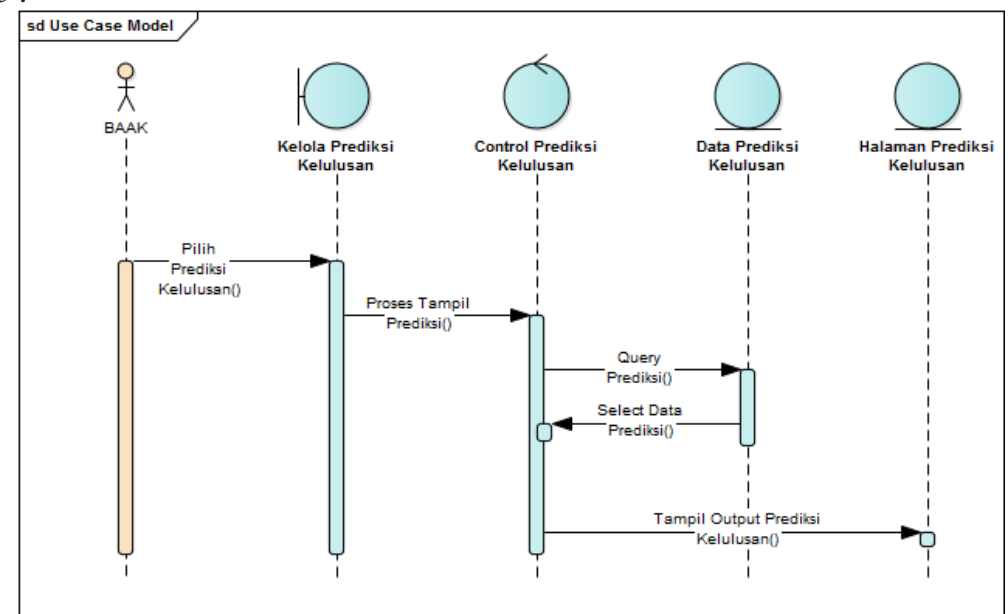

Gambar 7. Sequence Diagram Prediksi Kelulusan

\section{5). Class Diagram}

Class Diagram adalah diagram yang digunakan untuk mempresentasikan kelas, komponenkomponen kelas dan hubungan antara masing-masing kelas. Selain itu class diagram mendeskripsikan jenis-jenis objek dalam sistem dan berbagai macam hubungan statis yang terdapat diantara mereka.

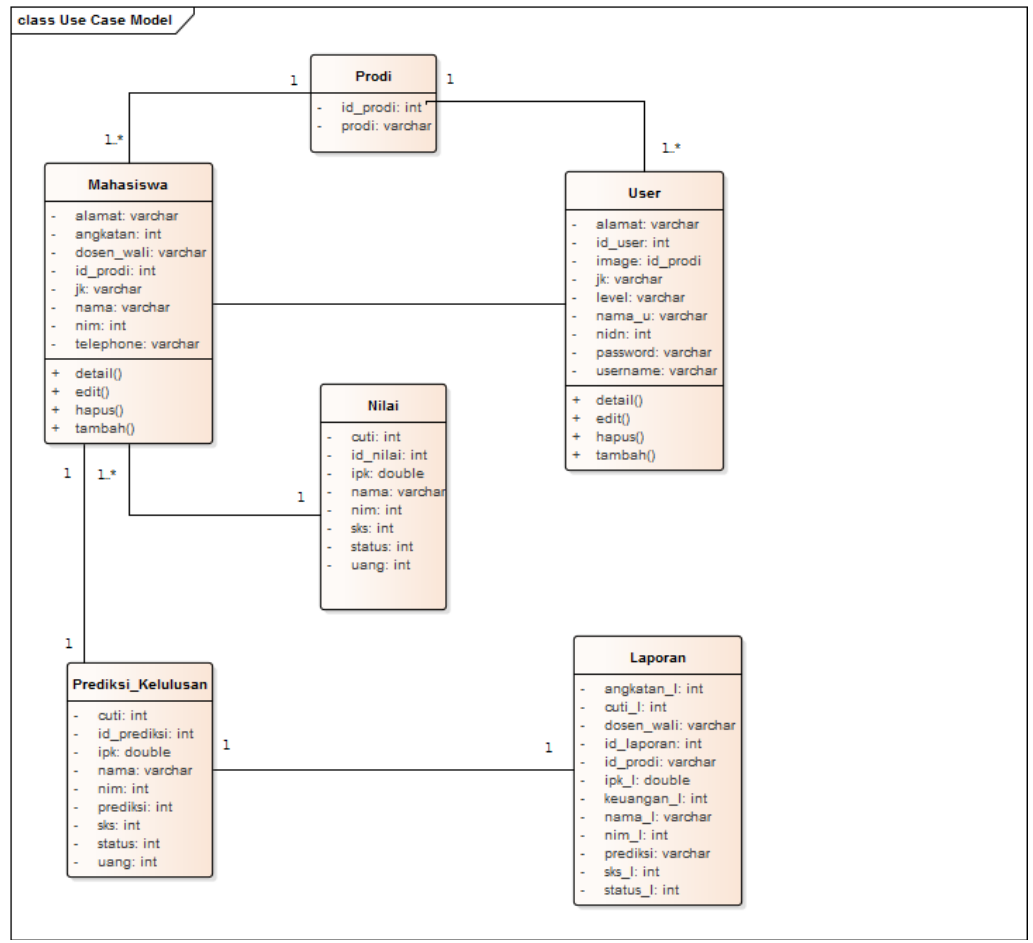

Gambar 8. Class Diagram

Sistem Prediksi Ketepatan Kelulusan Mahasiswa Berdasarkan Data Akedemik Dan Non-Akademik Menggunakan Metode K-Means (Studi Kasus : Universitas Catur Insan Cendekia) (Mochamad Rizky Alvin Fernanda, Petrus Sokibi, Rifqi Fahrudin) 


\section{Implementasi Dan Pengujian Sistem}

4.1. Tampilan Program

a. Halaman Login

Pada form login ini, pengguna sistem seperti BAAK dan Kaprodi dapat memasukan username, password dan level untuk dapat masuk ke halaman masing-masing level user.

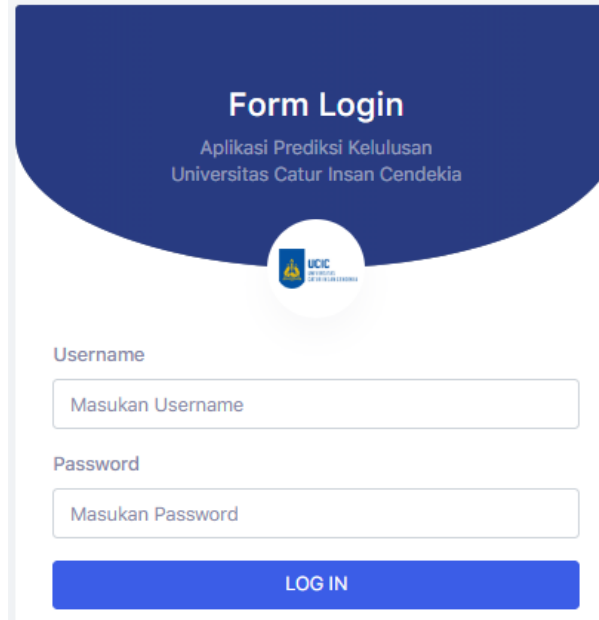

(C) 2020, Prediksi Kelulusan - Universitas CIC

Design by Rizky Alvin

\section{Gambar 9. Form Login Sistem}

\section{b. Halaman Form Tambah Mahasiswa}

Pada halaman form tambah mahasiswa ini, BAAK dapat menambahkan data mahasiswa yang berisi nim, nama mahasiswa, jenis kelamin, angkatan, jurusan, alamat, nomer telephone, dosen wali, IPK, SKS, keuangan, cuti.

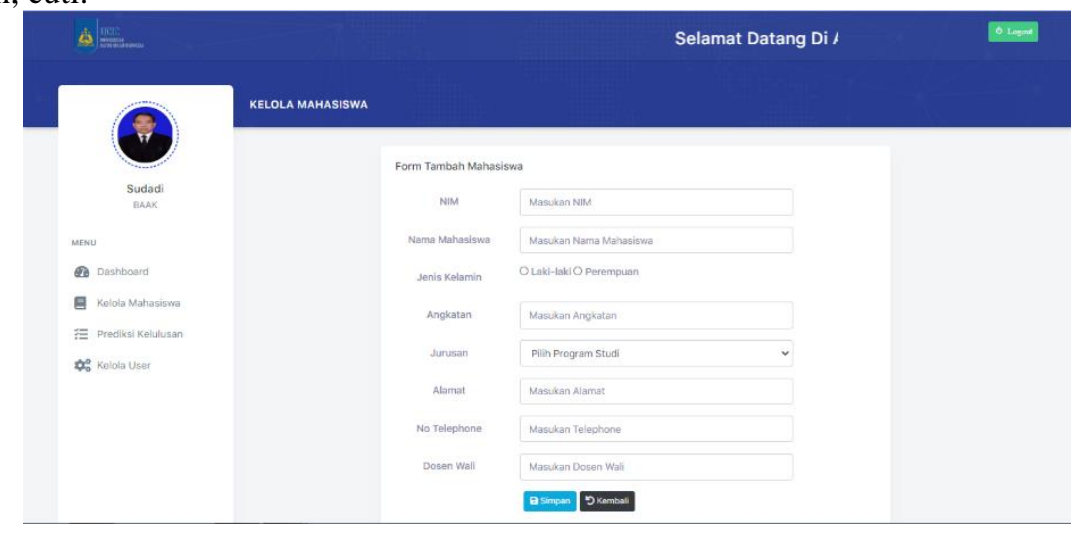

Gambar 10. Halaman Form Tambah Mahasiswa

c. Halaman Form Penilaian Mahasiswa

Pada halaman form penilaian mahasiswa ini, BAAK dapat menambah data nilai mahasiswa yang berisi nim, nama mahasiswa, IPK, SKS, keuangan, cuti, status. 


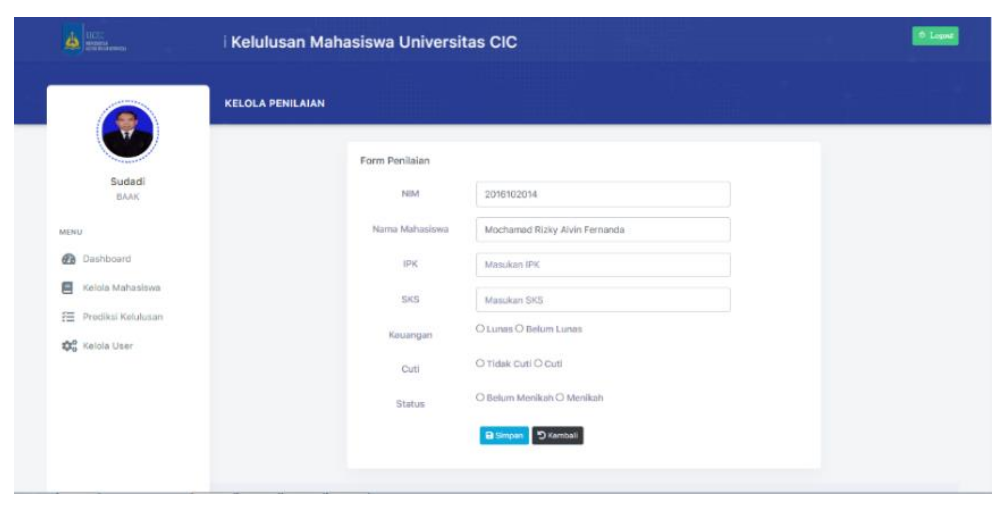

Gambar 11. Halaman Form Penilaian Mahasiswa

\section{d. Halaman Prediksi Kelulusan}

Pada halaman prediksi kelulusan ini, menampilkan data akademik dan non akademik berdasarkan nim, nama mahasiswa, IPK, SKS, keuangan, cuti dan status.

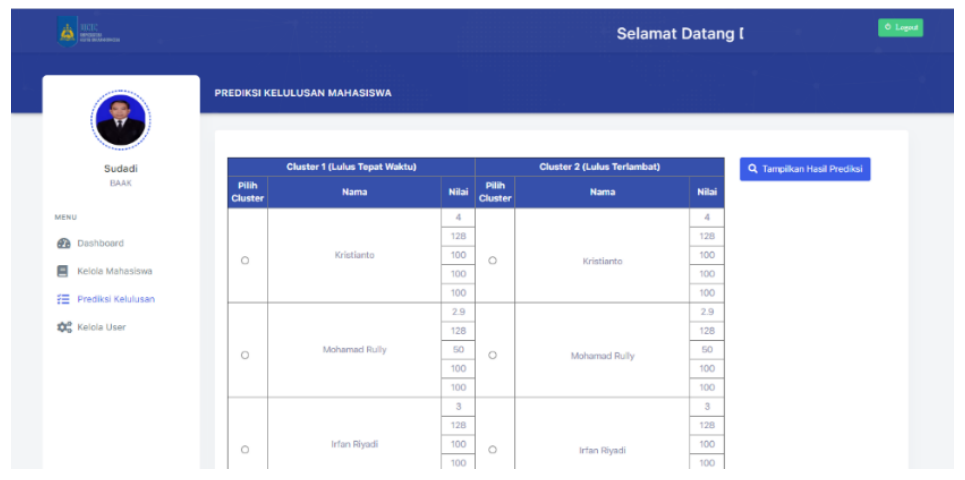

Gambar 12. Halaman Prediksi Kelulusan

\section{e. Halaman Prediksi Kelulusan}

Pada halaman prediksi kelulusan ini, menampilkan data akademik dan non akademik berdasarkan nim, nama mahasiswa, IPK, SKS, keuangan, cuti dan status.

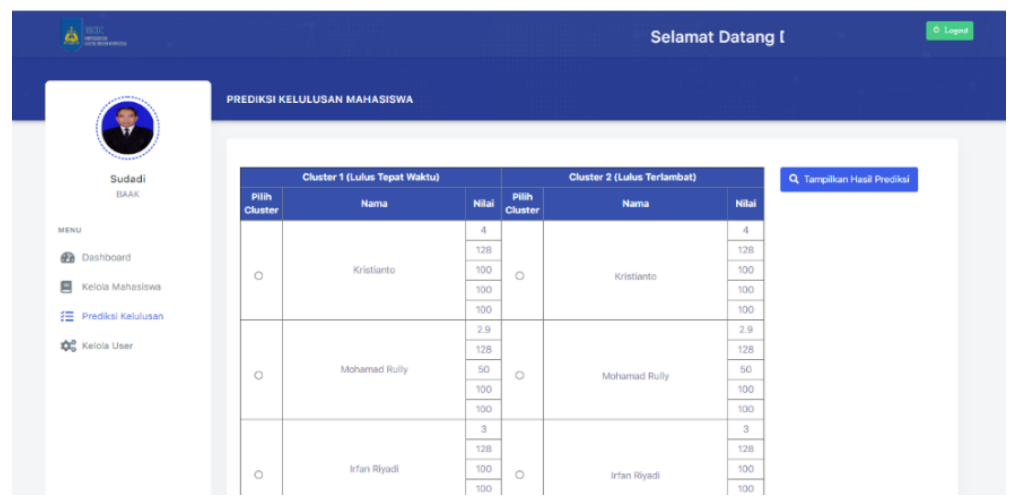

Gambar 12. Halaman Prediksi Kelulusan

Sistem Prediksi Ketepatan Kelulusan Mahasiswa Berdasarkan Data Akedemik Dan Non-Akademik Menggunakan Metode K-Means (Studi Kasus : Universitas Catur Insan Cendekia) (Mochamad Rizky Alvin Fernanda, Petrus Sokibi, Rifqi Fahrudin) 
a. Halaman Hasil Prediksi Kelulusan

Pada halaman hasil prediksi ini, menampilkan hasil prediksi kelulusan mahasiswa berdasarkan data akademik non akademik dan di halaman ini juga menyediakan fitur cetak untuk laporan.

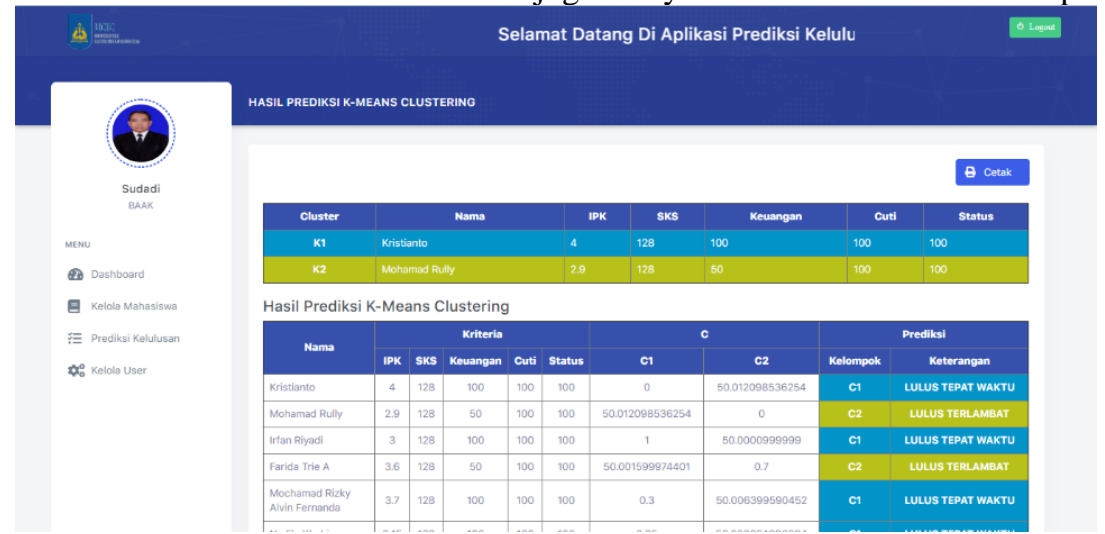

Gambar 13. Halaman Hasil Prediksi Kelulusan

\section{KESIMPULAN DAN SARAN}

\subsection{Kesimpulan}

Berdasarkan hasil implementasi dan pengujian sistem prediksi kelulusan mahasiswa dengan metode K-Means Clustering, maka dapat disimpulkan sebagai berikut :

1. Belum tersedianya aplikasi prediksi ketepatan kelulusan mahasiswa di Universitas Catur Insan Cendekia dan metode $K$-Means Clustering merupakan salah satu metode yang dapat menyelesaian permasalahan prediksi kelulusan mahasiswa di Universitas Catur Insan Cendekia.

2. Dari hasil perhitungan metode K-Means Clustering tersebut dapat menghasilkan prediksi kelulusan mahasiswa dengan lulus tepat waktu dan lulus terlambat di Universitas Catur Insan Cendekia.

3. Dapat mengetahui jumlah mahasiswa lulus berdasarkan tahun angkatan di Universitas Catur Insan Cendekia.

\subsection{Saran}

Sistem prediksi kelulusan mahasiswa dengan metode K-Means Clustering yang telah dibangun ini masih banyak kekurangan. Adapun saran yang dapat diberikan untuk pengembangan dari penelitian ini selanjutnya, antara lain :

1. Hasil prediksi kelulusan bisa dikombinasikan atau dibandingan dengan metode sistem klasifikasi lainnya seperti Nä̈ve Bayes, K-Nearest Neightbors, Online Analytical Processing atau metode sistem klasifikasi lainnya.

2. Serta sistem dapat dikembangkan dengan versi android dan memudahkan user dalam prediksi kelulusan mahasiswa.

3. Untuk tingkat akurasi data real dengan data diuji yaitu mencapai $90 \%$ benar. Berdasarkan 20 data sample yang diuji dan lulus tepat waktu sebesar 17 data mahasiswa dan lulus terlambat 3 data mahasiswa . Data real menghasilkan 20 data mahasiswa berhasil lulus tepat waktu semua.

\section{DAFTAR PUSTAKA}

[1] R. Agustia, A. A. Supianto, and N. H. Wardani, “Aplikasi Data Mining menggunakan Algoritme Naive Bayes untuk Memprediksi Ketepatan Waktu Lulus Mahasiswa," vol. 3, no. 7, pp. 6303-6310, 2019.

[2] D. M. A. B. Pramudita Oktaviani1, Ibnu Asror, S.T., M.T.2, “Analisis Implementasi Sistem OLAP dan Klasifikasi Ketepatan Waktu Lulus dan Undur Diri Mahasiswa Teknik Informatika Universitas Telkom Menggunakan Random forest," Eval. ISSN 2355-9365, vol. Vol.5, No., 2018.

[3] R. Muliono, "Analisis Algoritma K-Nearest Neighbors dalam Prediksi Waktu Kelulusan Mahasiswa," vol. 2, no. November, pp. 12-16, 2019. 
[4] A. S. Kusuma and K. S. Aryati, "Sistem Informasi Akademik Serta Penentuan Kelas Unggulan dengan Algoritama K-Means di SMP Negeri 3 Ubud," vol. 1, no. 3, 2019.

[5] M. I. Muhdlari et al., "ANALISIS VARIASI NILAI MOMENTUM DALAM PREDIKSI HARGA IKAN LELE MENGGUNAKAN METODE BACKPROPAGATION,” pp. 1-9, 2019.

[6] K. Pustaka, "Penerapan Algoritma Decision Tree Id3 Untuk Prediksi Kelulusan Mahasiswa Jenjang Pendidikan D3 Di Fakultas Teknik Universitas Pandanaran,” Neo Tek., vol. 5, no. 2, pp. 1-6, 2019, doi: 10.37760/neoteknika.v5i2.1391.

[7] A. Dkbpp and K. Bangkalan, "IMPLEMENTASI K-MEANS CLUSTERING UNTUK PEMETAAN DESA DAN KELURAHAN DI CONTRACEPTIVE PREVALENCE RATE DAN," 2017.

[8] L. Magdalena and R. Fahrudin, "Penerapan Data Mining Untuk Koperasi Se-Jawa Barat Menggunakan Metode Clustering pada Kementerian Koperasi dan UKM,” J. Digit, vol. 9, no. 2, pp. 190-201, 2019

[9] I. Lubis, D. Handoko, U. H. Medan, P. Studi, T. Informatika, and S. I. Manajemen, "ANALISA DAN RANCANGAN SISTEM INFORMASI MANAJEMEN,” vol. 3, no. 2, 2019. 